\title{
Testing the Relationship between Government Revenue and Expenditure: Evidence from Nigeria
}

\author{
Kanayo Ogujiuba ${ }^{1} \&$ Terfa W. Abraham ${ }^{2}$ \\ ${ }^{1}$ Senior Research Fellow, National Institute for Legislative Studies (NILS), National Assembly, Maitama-Abuja \\ and Affiliate of the Department of Statistics and Population Studies, University of Western Cape, Cape Town, \\ South Africa \\ ${ }^{2}$ Research Officer, National Institute for Legislative Studies (NILS), National Assembly, Maitama - Abuja \\ (Nigeria) and PhD Student of the Department of Economics, Usmanu Danfodiyo University, Sokoto State, \\ Nigeria \\ Correspondence: Kanayo Ogujiuba, National Institute for Legislative Studies (NILS), National Assembly, No. 1 \\ River Niger Street, off Danube Street, Maitama-Abuja, Nigeria. Tel: 234-803-384-3538. E-mail: \\ kannyog@gmail.com
}

Received: September 5, 2012

Accepted: October 3, $2012 \quad$ Online Published: October 15, 2012

doi:10.5539/ijef.v4n11p172

URL: http://dx.doi.org/10.5539/ijef.v4n11p172

\begin{abstract}
The paper examines the revenue-spending hypothesis for Nigeria using macro data from 1970 to 2011 . Correlation analysis, granger causality test, regression analysis, lag regression model, vector error correction model and impulse response analysis were the techniques used for analysis. The paper found that revenue and expenditure are highly correlated and that causality runs from revenue to expenditure in Nigeria. The vector error correction model also confirms that there is a significant long run relationship between revenue and expenditure implying that disequilibrium in expenditure can be corrected in the long run through policies that adjust oil and non-oil sector revenues. The lagged regression model showed that the positive relationship between revenue and expenditure reverts to negative at lag five thereby justifying the need for the use of medium term expenditure framework to monitor expenditure patterns in the short to medium term. The paper concludes that short term shocks from crude oil price passes through oil revenue to affect expenditure. This has led to swings in public expenditure pattern with sustained increase of recurrent expenditure over capital that has consequences for economic growth. Putting policies in place to enhance the performance of the non-oil sector and adopting expenditure framework that accounts for possible decline in crude oil prices was conceived as useful in enhancing a healthy revenue-expenditure relationship in Nigeria.
\end{abstract}

Keywords: revenue, expenditure, time series analysis, Nigeria

\section{Introduction}

The debate on the relationship between government revenue and spending has been the focus of several studies (e.g. Stoian, 2008; Obioma \& Ozughalu, 2010; Mehmood \& Sadiq, 2010; Aregbeyen \& Ibrahim, 2012). These studies however provide some empirical gaps that can be improved upon. The aim of this paper is to examine the relationship of revenue and public spending in Nigeria from 1970 to 2010. The paper contributes to the literature by updating the data used and improves on the methodological gaps found in related studies. The paper also examines the response of expenditure to revenue shock so as to make policy deductions that would be relevant for Nigeria's expenditure framework.

Stoian (2008) examined the relationship between public revenues and expenditures in Romania. Regression analysis, Correlation and Granger causality analysis where used for the analysis. The results found a significant relationship between the variables. The paper argued that the direction of causality (that runs from revenue to expenditure) implied that some adjustments are required in revenues to achieve desired targets of expenditures. The paper also argued that expenditures could respond to lagged values of revenues but did not provide empirical evidence in that direction. From the granger causality result also, the paper deduced there could be along run equilibrium between revenue and expenditure that could be reached by through short run adjustments in revenue. Empirical evidence that shows such possibility was also not presented in the paper. More so, specific economies are likely to respond to shocks from their major exports, like crude oil for Nigeria. Providing 
evidence on expenditure response to major revenue shock channels would therefore be important as well. Obioma and Ozughalu (2010) examined the empirical relationship between government revenue and government expenditure in Nigeria using time series data from 1970 to 2007. The paper used the Engel-Granger two-step cointegration technique, the Johansen cointegration method and the Granger causality test within the Error Correction Modeling (ECM) for analysis. It found that there is a long-run relationship between government revenue and government expenditure in Nigeria and evidence of a unidirectional causality from government revenue to government expenditure. It however did not model expenditure response to shocks from revenue.

Mehmood and Sadiq (2010) examined the short and long run relationship between the fiscal deficits and poverty in Pakistan using time series data from 1976 to 2010. The short run relationship was examined using error correction model while Johansen cointegration analysis was used to examine the long run relationship. The paper found that there is a negative relationship between government expenditure both in short and long run in Pakistan. Though the authors used Johansen cointegration model to estimate the long run relationship, vector error correction model would have been preferred to provide for short run and long run relationship using a single framework. Normality test should also have been added to the stationarity test in order to avoid spurious regression results. Aregbeyen and Ibrahim (2012) examined the long-run relationship and the dynamic interaction between government revenues and expenditures in Nigeria from 1970 to 2008 using Autoregressive Distributed Lag (ARDL) bound test approach. The paper introduced an innovation that examined the relationship of revenue and expenditure but did not test for their direction of influence. Thus, it is not clear why they revenue (or expenditure) was specified as dependent (or independent) variable.

\subsection{Revenue and Expenditure Pattern in Nigeria: 1970 To 2011}

Revenue and expenditure in Nigeria have behaved in a procyclical nature since 1970. Table 1 shows that expenditure changed by $85 \%$ within the period 1970 to 1975 . This was attributed to the oil boom that was witnessed within the period and led to the expansion of government involvement in the economy that was characterized by nationalization programmes.

Table 1. Change in Total Government Spending and Revenue in Selected Periods

\begin{tabular}{|c|c|c|c|c|c|c|c|c|c|}
\hline Items & $1970-1975$ & $1975-1980$ & $1979-1984$ & $1985-1990$ & $1995-1997$ & $1997-2000$ & $2000-2003$ & $2003-2007$ & $2007-2011$ \\
\hline Change in Expenditure & $85 \%$ & $60.29 \%$ & 34.04 & $78.36 \%$ & $41.91 \%$ & $38.92 \%$ & $42.82 \%$ & $49.98 \%$ & $45.33 \%$ \\
\hline ERecurrent (Nm) & $7,767.5$ & $21,161.9$ & $28,923.40$ & $112,542.7$ & $410,684.6$ & $1,247,923.7$ & $2,722,000.0$ & $6,120,171.9$ & $12,653,170.7$ \\
\hline$\Sigma$ Capital (Nm) & $5,809.6$ & $31,836.4$ & $36,352.80$ & $67,786.8$ & $603,716.3$ & $1,316,145.8$ & $1,241,213.8$ & $2,424,197.1$ & $5,065,452.8$ \\
\hline $\begin{array}{l}\text { Average crude oil prices } \\
\text { (USD) }\end{array}$ & 24.47 & 63.15 & 78.41 & 31.36 & 25.91 & 25.23 & 32.14 & 56.24 & 88.15 \\
\hline $\begin{array}{l}\text { Average Inflation Rate } \\
\text { (12MMA) }\end{array}$ & $10.8 \%$ & $18.6 \%$ & $19.0 \%$ & $22.4 \%$ & $37.6 \%$ & $8.0 \%$ & $13.2 \%$ & $12.1 \%$ & $10.5 \%$ \\
\hline $\begin{array}{l}\text { Average Exchange rate } \\
\text { (Naira/USD) }\end{array}$ & 0.6619 & 0.6062 & 0.6523 & 4.4831 & 21.8861 & 59.6427 & 116.0938 & 129.8977 & 139.4920 \\
\hline
\end{tabular}

Source: Authors' calculation based on National Statistics

From 1975 to 1980 , public expenditure fell by $24.71 \%$ to $60.29 \%$. This was due to the creation of new states in February 1976 and the decline in the level of oil production during the 1975/76 fiscal year. The focus of the third development plan from 1975-1980 to finance water supply, health, agriculture and co-operative projects also necessitated the rise of capital expenditure above recurrent expenditure. The decline in the level of oil production saw global crude oil price rising from an average of USD24.47 within 1970-1975 to USD63.15 in 1975-1980; which helped to close the deficit spending gap. Average inflation rate within this period however had gone up by $7.8 \%$ while exchange rate appreciated against the dollar $8.42 \%$ implying low value for money and higher real project costs/higher cost of living.

Within 1979-1984, public expenditure had further dropped by $26.25 \%$ to $34.04 \%$ compared to $60.29 \%$. A major reason for this was the need for the then administration to address the worsening of economic conditions which led to the introduction of the Economic Stabilization Act of April 1982. The stabilization measures were, to a large extent, implemented through administrative controls such as tightening of import controls, imposition of exchange restrictions on current international transactions, substantial increases in customs tariffs, introduction of an advance import deposit scheme, and ceilings on total central bank foreign exchange disbursements (NCEMA, 2004). The fourth national development plan (1981-1985) therefore re-emphasized the need for 
agricultural-based self reliance but, suffered from foreign exchange shortages, which led to widespread scarcity of essential commodities and high food cost.

By the 1985-1990, the administration at the time saw the need to free resources by liberalizing the economy. Thus, Structural Adjustment Programme (SAP) was put in place. The objectives of SAP were among, to position the private sector as the engine of economic growth, to liberalize the economy and to hold back on government involvement in the economy. Government expenditure within the period soared as recurrent expenditure rose above capital expenditure by $59.82 \%$. Average crude oil price fell by more than $47 \%$ while inflation rose $3.4 \%$ to $22.4 \%$. The naira depreciated by about $85 \%$ moving from N0.6523 to the USD within 1979-1984 to N4.4831 within 1985-1990. Economic hardship within this period increased and rolling plans replaced development plans.

From 1990 to 1996, four national rolling plans had already been implemented. By 1995-1997 however, exchange rate further depreciated by $79.53 \%$ to 21.88 to the USD and inflation rate rose by $15.2 \%$ to $37.6 \%$. The federal government maintained deficit spending which led to increased external and domestic debt to N643,372.50 million and N466,486.86 respectively within 1995-1997. These figures were the highest since Nigeria's independence. By 1997-2000, capital expenditure was slightly higher than recurrent expenditure. With the return to democracy in 1999 there were therefore high expectations on achieving sustainable growth through sound fiscal management.

The creation of new democratic institutions however, saw recurrent expenditure rising over capital expenditure within 2000-2003. The huge debt inherited from the military era made the financing of capital projects difficult and expensive. Though crude oil price had improved by this period from an average of USD32.14 in the previous period to USD 56.24, the devaluation of the naira, made it difficult for Nigeria to reap the gains of rising crude oil price as pipeline vandalism was also the order of the day at the time.

By 2007-2011 the global economy witnessed severe recession and Nigeria was not exempted from its adverse impacts. Declining crude oil price also compounded the impact of the crisis on revenue in Nigeria. This translated into further devaluation of the naira by $6.88 \%$ to N139.49 from an average of N129.89 in the previous period and expanded the deficit spending gap.

\section{Methods and Techniques}

Following Stoian (2008) and Mehmood and Sadiq (2010) paper employed the following techniques for analysis: correlation analysis, Granger causality, regression analysis, lagged regression model and vector error correction model. Real time series data were collected for the following variables for the period 1970-2011 from the Central bank of Nigeria: federally collected public expenditure (EXPN), federally collected revenue (REV), revenue from crude oil (OREV), non-oil revenue (NOREV) and crude oil price in USD (COP) from the web. The variables were also used in Obioma and Ozughalu (2010) and Aregbeyen and Ibrahim (2012). The variables were tested for stationarity and normality before the estimations were done.

The correlation coefficient is computed using:

$$
r_{x y}=\Sigma z_{x} z_{y} / N
$$

where $\mathrm{r}_{\mathrm{xy}}$ is the correlation coefficient, $\mathrm{Z}_{\mathrm{x}}$ is the variables converted in $\mathrm{z}$ scores to be correlated with $\mathrm{Z}_{\mathrm{y}}$ variables to obtain $\mathrm{r}$, and $\mathrm{N}$ is the number of observation (1970-2011) for 42 observations. The a priori is that $\mathrm{r}>0$ for all the variables.

The direction of causality among the variables will be examined using Granger causality for expenditure (EXPN) and revenue (REV) is specified as:

$$
\begin{aligned}
& E X P N_{t}=\alpha_{0}+\alpha_{i} \sum_{\mathrm{i}=1}^{\mathrm{n}} E X N_{t-i}+\beta i \sum_{\mathrm{i}=1}^{\mathrm{n}} R E V_{t-I}+e_{t} \\
& R E V_{t}=\alpha_{0}+\underset{\mathrm{i}=1}{\alpha_{i} \Sigma R E V_{t-i}}+\underset{\mathrm{i}=1}{\beta i \Sigma} \operatorname{EXPN}_{t-i}^{\mathrm{n}}+e_{t}
\end{aligned}
$$

Where $\alpha_{0}$ and $\beta_{\mathrm{i}}$ are coefficients and $\mathrm{e}_{\mathrm{t}}$ is the residual. It is expected that EXPN and REV will have a bi-directional relationship i.e. $\alpha_{\mathrm{i}}>0$ and $\beta \mathrm{i}>0$. Revenue is also be broken down into oil revenue (OREV) and non-oil revenue (OREV) and substituted in the model to obtain the direction of causality. Crude oil price (COP) will also be substituted to obtain the direction of causality with expenditure (EXPN). 
The regression model is specified as:

$$
\triangle \text { EXPN }_{\mathrm{t}}=\mathrm{a}_{\mathrm{o}}+\mathrm{a}_{1} \Delta \operatorname{REV}_{\mathrm{t}}+\mathrm{a}_{2} \Delta \mathrm{OREV}_{\mathrm{t}}+\mathrm{a}_{3} \Delta \mathrm{NOREV}_{\mathrm{t}}+\mathrm{a}_{4} \Delta \mathrm{COP}_{\mathrm{t}}+\mathrm{u}_{\mathrm{t}}
$$

Where $\Delta$ is the differencing sign to correct for unit root and a1-4 are coefficients showing the relationship between the independent variables and the dependent variable. The a priori expectation is that $\mathrm{a}_{1}>1, \mathrm{a}_{2}>0, \mathrm{a}_{3}>0$ and $\mathrm{a}_{4}<0$.

Lagged regression model will also be estimated connecting expenditure and revenue at lag five. It will be expected that coefficient will be negative as revenue in Nigeria is driven by crude oil price which can be difficult to predict beyond 5 years. The model is specified as:

$$
\Delta \mathrm{EXPN}_{\mathrm{t}}=\mathrm{b}_{\mathrm{o}}+\mathrm{b}_{1} \Delta \mathrm{REV}_{\mathrm{t}}+\mathrm{b}_{2} \Delta \mathrm{REV}_{\mathrm{t}-5}+\mathrm{u}_{\mathrm{t}}
$$

Where $b_{1}>0 ; b_{2}<0$.

The vector error correction model is specified thus:

$$
\Delta x_{t}=\Pi x_{t-1}+\sum_{\mathrm{I}=1}^{\mathrm{p}-1} \phi \ddot{\Delta} \Delta x_{t-I}+\epsilon_{t}
$$

where $\epsilon_{t}$ is the error term, $\Pi$ and the $\Phi$ are functions of the $\Phi$ 's. If $\Pi=0$, then there is no cointegration. Nonstationarity of $I(\mathrm{I})$ type vanishes by taking differences $(\Delta)$. The model interprets that there is an adjustment to the 'equilibrium' $x *$ or long term relation described by the cointegrating relation while $\Pi$ captures the short run relationship and the adjustment required to arrive at the long run equilibrium. The models will be estimated using Eviews econometric package.

\section{Results}

\subsection{Correlation Analysis}

Correlation analysis was conducted on the data to establish the degree of association connecting the variables. It was found that all the variables are positively associated by $99 \%$ except for COP which had a low correlation value of about $30 \%$ with the other variables. The correlation matrix result is presented in Table 2 .

Table 2. Correlation Matrix

\begin{tabular}{lccccc}
\hline & EXPN & REV & OREV & NOREV & COP \\
\hline EXPN & 1.000000 & 0.995498 & 0.992554 & 0.992272 & 0.312008 \\
REV & 0.995498 & 1.000000 & 0.998226 & 0.992640 & 0.326349 \\
OREV & 0.992554 & 0.998226 & 1.000000 & 0.985061 & 0.349530 \\
NOREV & 0.992272 & 0.992640 & 0.985061 & 1.000000 & 0.280679 \\
COP & 0.312008 & 0.326349 & 0.349530 & 0.280679 & 1.000000 \\
\hline
\end{tabular}

Source: Authors Computation

\subsection{Granger Causality}

Though correlation analysis shows the degree of association between two variables, it does not tell the direction of causality i.e. whether the changes in one of the variables is attributed to changes in the other variable. Granger causality test addresses this short coming. The granger causality result is presented in Table 3: 
Table 3. Granger Causality Test

\begin{tabular}{|c|c|c|c|}
\hline \multicolumn{4}{|l|}{$\begin{array}{l}\text { Pairwise Granger Causality Tests } \\
\text { Sample: } 19702011 \\
\text { Lags: } 2\end{array}$} \\
\hline Null Hypothesis: & Obs & F-Statistic & Probability \\
\hline (1) REV does not Granger Cause EXPN & 40 & 3.21726 & 0.05216 \\
\hline EXPN does not Granger Cause REV & & 2.09693 & 0.13800 \\
\hline (2) OREV does not Granger Cause EXPN & 40 & 3.48308 & 0.04173 \\
\hline EXPN does not Granger Cause OREV & & 2.60493 & 0.08818 \\
\hline (3) NOREV does not Granger Cause EXPN & 40 & 0.41740 & 0.66199 \\
\hline EXPN does not Granger Cause NOREV & & 7.16248 & 0.00247 \\
\hline (4) COP does not Granger Cause EXPN & 40 & 3.58235 & 0.03842 \\
\hline EXPN does not Granger Cause COP & & 0.55271 & 0.58033 \\
\hline (5) COP does not Granger Cause REV & 40 & 5.95284 & 0.00595 \\
\hline REV does not Granger Cause COP & & 2.94757 & 0.06561 \\
\hline (6) COP does not Granger Cause OREV & 40 & 8.13425 & 0.00126 \\
\hline OREV does not Granger Cause COP & & 3.99592 & 0.02735 \\
\hline (7) COP does not Granger Cause NOREV & 40 & 0.67767 & 0.51433 \\
\hline NOREV does not Granger Cause COP & & 0.15050 & 0.86084 \\
\hline
\end{tabular}

Source: Authors Computation

Table 3 show that revenue granger-causes expenditure at $10 \%$ level of significance but expenditure does not granger-cause revenue implying that, there is a unidirectional influence running from revenue to expenditure. The result is shown in line (1) in Table 3.2 above.Breaking revenue into two parts (oil revenue and non-revenue) showed that oil revenue granger-causes expenditure and the result was significant at $5 \%$ critical value. Though expenditure as well was found to granger-cause oil revenue, the result which is presented in line (2) of Table 3.2, was significant at $10 \%$ critical value implying lesser significance compared to the influence oil revenue has on expenditure compared. Non-oil revenue however does not lead to changes in expenditure rather expenditure was found to granger-cause non-oil revenue with significance at $1 \%$ critical value. This implies that public expenditure, which is large driven by the oil sector in Nigeria, should be used to develop the non-oil sector in order to get the non-oil sector contribute the growth of public expenditure in Nigeria. The result is presented in line (3) of Table 3.

Fluctuations in crude oil price were also found to granger-cause public expenditure in Nigeria. This is shown in line (4) of Table 3.2 as the probability value of the computed F-statistic was significant $5 \%$ critical value while. This implies that variability in crude oil prices would significantly affect the public expenditure pattern in Nigeria. The channel through which oil revenue affects expenditure however is through revenue. Thus the granger causality result in line (5) shows that crude oil price granger-causes i.e. has a short run influence on total revenue in Nigeria. The result is significant at $1 \%$ critical value. When separated into oil and non-oil revenue, crude oil price was found to influence oil revenue at a significant value of $1 \%$ critical value, while there was no causality found running from crude oil price to non-oil revenue. The results are contained in lines (6) and (7) of Table 3 respectively.

In summary, the granger causality test confirms the revenue-spend hypothesis at $10 \%$ critical value while the hypothesis for spend-revenue is rejected. The short coming of the granger causality test is that it does not show the direction of relationship between two variables. Although it is used to show that changes in revenue affects expenditure but it does not tell whether it is positive or negative changes or the size of the impact in terms of a coefficient of determination. The ordinary least square regression technique addresses this short coming.

\subsection{Ordinary Least Square Regression Result}

This technique requires that the variables should be stationary and normally distributed before estimation is conducted. When tested for stationarity using the augmented dickey fuller unit root test, it was found that all the variables were stationary at first difference therefore requiring that the variables be differenced by one during estimation. The stationarity result is presented in Table 4: 
Table 4. STATIONARITY TEST: Augmented Dickey Fuller (ADF) Test

\begin{tabular}{lllll}
\hline Level test $I(0)$ & & \multicolumn{3}{l}{ Critical Values } \\
\hline ADF Stat & Variables & $1 \%$ & $5 \%$ & $10 \%$ \\
\hline-0.7711 & Expenditure (EXPN) & -3.5973 & -2.9339 & -2.6048 \\
-1.0022 & Revenue (REV) & -3.5973 & -2.9339 & -2.6048 \\
-1.7473 & Oil Revenue (OREV) & -3.5973 & -2.9339 & -2.6048 \\
-0.2077 & Non-Oil Revenue (NOREV) & -3.5973 & -2.9339 & -2.6048 \\
-2.0491 & Crude oil Price (COP) & -3.5973 & -2.9339 & -2.6048 \\
\hline First Difference Test $I(1)$ & & & -2.6059 \\
\hline-7.4387 & Expenditure (EXPN) & -3.6019 & -2.9358 & -2.6059 \\
-7.1407 & Revenue (REV) & -3.6019 & -2.9358 & -2.6059 \\
-7.2685 & Oil Revenue (OREV) & -3.6019 & -2.9358 & -2.6059 \\
-8.1661 & Non-Oil Revenue (NOREV) & -3.6019 & -2.9358 & -2.6059 \\
-6.4247 & Crude oil Price (COP) & -3.6019 & -2.9358 & \\
\hline
\end{tabular}

Source: Authors Computation (Eviews)

The Jarque-Bera statistics was used to test for normality in the distribution of the data. Of all the variables, only expenditure (EXPN) and revenue (REV) were found to be normally distributed since their Jarque-Bera statistics values were approximately 3 and the values of their skewness approximately zero. The Jarque-Bera result is presented in Table 5:

Table 5. Jarque-Bera Statistics

\begin{tabular}{lccccc}
\hline & EXPN & REV & OREV & NOREV & COP \\
\hline Mean & 4.900476 & 5.042857 & 4.897615 & 4.443419 & 1.592187 \\
Median & 4.800000 & 4.995000 & 4.886990 & 4.340802 & 1.570312 \\
Maximum & 6.650000 & 6.950000 & 6.814955 & 6.333246 & 2.056600 \\
Minimum & 2.960000 & 2.800000 & 2.221675 & 2.669689 & 0.997386 \\
Std. Dev. & 1.135133 & 1.262551 & 1.310474 & 1.184348 & 0.264085 \\
Skewness & 0.004034 & 0.052903 & -0.051385 & 0.154457 & -0.239057 \\
Kurtosis & 1.702095 & 1.680241 & 1.837705 & 1.586509 & 2.455340 \\
Jarque-Bera & 2.948089 & 3.067680 & 2.382611 & 3.663421 & 0.919183 \\
Probability & 0.228997 & 0.215706 & 0.303824 & 0.160139 & 0.631542 \\
Observations & 42 & 42 & 42 & 42 & 42 \\
\hline
\end{tabular}

Source: Authors Computation using Eviews

The multiple regression result was then estimated using all the variables. The result showed that none of the coefficients were significant by their t-statistics value. The multiple regression result is presented in Table 6 . 
Table 6. Multiple Regression Results

\begin{tabular}{|c|c|c|c|c|}
\hline \multicolumn{5}{|c|}{ Dependent Variable: D(EXPN) } \\
\hline \multicolumn{5}{|c|}{ Method: Least Squares } \\
\hline \multicolumn{5}{|c|}{ Date: $07 / 14 / 12 \quad$ Time: $12: 46$} \\
\hline \multicolumn{5}{|c|}{ Sample(adjusted): 19712011} \\
\hline \multicolumn{5}{|c|}{ Included observations: 41 after adjusting endpoints } \\
\hline Variable & Coefficient & Std. Error & $\mathrm{t}$-Statistic & Prob. \\
\hline $\mathrm{C}$ & 0.045713 & 0.021673 & 2.109240 & 0.0419 \\
\hline $\mathrm{D}(\mathrm{REV})$ & 0.410448 & 0.656922 & 0.624804 & 0.5360 \\
\hline $\mathrm{D}(\mathrm{OREV})$ & 0.009425 & 0.453908 & 0.020765 & 0.9835 \\
\hline D(NOREV) & 0.084061 & 0.183019 & 0.459299 & 0.6488 \\
\hline $\mathrm{D}(\mathrm{COP})$ & -0.225022 & 0.202428 & -1.111615 & 0.2737 \\
\hline R-squared & 0.215308 & \multicolumn{2}{|c|}{ Mean dependent var } & 0.090000 \\
\hline Adjusted R-squared & 0.128120 & \multicolumn{2}{|c|}{ S.D. dependent var } & 0.111826 \\
\hline S.E. of regression & 0.104417 & \multicolumn{2}{|c|}{ Akaike info criterion } & -1.567004 \\
\hline Sum squared resid & 0.392503 & \multicolumn{2}{|c|}{ Schwarz criterion } & -1.358032 \\
\hline Log likelihood & 37.12358 & \multicolumn{2}{|c|}{ F-statistic } & 2.469472 \\
\hline Durbin-Watson stat & 2.413408 & \multicolumn{2}{|c|}{ Prob(F-statistic) } & 0.062031 \\
\hline
\end{tabular}

Source: Authors Computation using Eviews

Looking at the probability values for the individual t-statistic value shows that the coefficients are not significant. All the variables were then dropped at the regression re-estimated taking into account only expenditure and revenue since they were both normally distributed. Expenditure is specified as the dependent variable because of the results from the granger-causality which confirms the revenue-spend hypothesis. The re-estimated result is presented in Table 7.

Table 7. Single Regression Result

\begin{tabular}{|c|c|c|c|c|}
\hline \multicolumn{5}{|c|}{ Dependent Variable: D(EXPN) } \\
\hline \multicolumn{5}{|c|}{ Method: Least Squares } \\
\hline \multicolumn{5}{|c|}{ Sample(adjusted): 19712011} \\
\hline \multicolumn{5}{|c|}{ Included observations: 41 after adjusting endpoints } \\
\hline Variable & Coefficient & Std. Error & $\mathrm{t}$-Statistic & Prob. \\
\hline $\mathrm{C}$ & 0.058844 & 0.020086 & 2.929552 & 0.0056 \\
\hline $\mathrm{D}(\mathrm{REV})$ & 0.307811 & 0.116199 & 2.648994 & 0.0116 \\
\hline R-squared & 0.152490 & \multicolumn{2}{|c|}{ Mean dependent var } & 0.090000 \\
\hline Adjusted R-squared & 0.130759 & \multicolumn{2}{|c|}{ S.D. dependent var } & 0.111826 \\
\hline S.E. of regression & 0.104259 & \multicolumn{2}{|c|}{ Akaike info criterion } & -1.636334 \\
\hline Sum squared resid & 0.423924 & \multicolumn{2}{|c|}{ Schwarz criterion } & -1.552745 \\
\hline Log likelihood & 35.54485 & \multicolumn{2}{|c|}{ F-statistic } & 7.017168 \\
\hline Durbin-Watson stat & 2.513903 & \multicolumn{2}{|c|}{ Prob(F-statistic) } & 0.011596 \\
\hline
\end{tabular}

Source: Authors Computation using Eviews

The result shows that there is a positive and significant relationship between public expenditure and revenue in Nigeria and supports the revenue-spend hypothesis for Nigeria indicating that increase in revenue implies increase in expenditure for Nigeria and decrease in revenue implies decrease in expenditure for Nigeria.

The implication for Nigeria's short to medium planning can be deduced by introducing lag values of the independent variable in the model. Revenue lagged to maximum period of 10 but the coefficient was only significant at revenue at present value and revenue at lag 5. The implication is that why it makes economic sense for current expenditure to increase due to increase recorded in revenue, it would be important to adopt a framework that allows for expenditure to decline in 5 years when revenue is increasing and increasing when revenue is declining. This would require factoring into Nigeria's medium expenditure framework measures that counteracts the procyclical nature revenue and expenditure in Nigeria. Such measure would be important to help Nigeria weather the storm in periods of dwindling crude oil prices. The lagged revenue model is presented in Table 8 . 
Table 8. Lagged Revenue Regression Result

\begin{tabular}{|c|c|c|c|c|}
\hline \multicolumn{5}{|c|}{ Dependent Variable: EXPN } \\
\hline \multicolumn{5}{|c|}{ Method: Least Squares } \\
\hline \multicolumn{5}{|c|}{ Sample(adjusted): 19762011} \\
\hline \multicolumn{5}{|c|}{ Included observations: 36 after adjusting endpoints } \\
\hline Variable & Coefficient & Std. Error & $\mathrm{t}$-Statistic & Prob. \\
\hline $\mathrm{C}$ & 0.073269 & 0.021356 & 3.430902 & 0.0016 \\
\hline REV & 0.380920 & 0.122380 & 3.112607 & 0.0038 \\
\hline REV $(-5)$ & -0.246342 & 0.120385 & -2.046278 & 0.0488 \\
\hline R-squared & 0.249937 & \multicolumn{2}{|c|}{ Mean dependent var } & 0.080000 \\
\hline Adjusted R-squared & 0.204479 & \multicolumn{2}{|c|}{ S.D. dependent var } & 0.106207 \\
\hline S.E. of regression & 0.094728 & \multicolumn{2}{|c|}{ Akaike info criterion } & -1.795950 \\
\hline Sum squared resid & 0.296125 & \multicolumn{2}{|c|}{ Schwarz criterion } & -1.663990 \\
\hline Log likelihood & 35.32709 & \multicolumn{2}{|c|}{ F-statistic } & 5.498159 \\
\hline Durbin-Watson stat & 2.499310 & \multicolumn{2}{|c|}{ Prob(F-statistic) } & 0.008692 \\
\hline
\end{tabular}

Source: Authors Computation using Eviews

\subsection{Test Results for Cointegration}

Understanding the long run relationship between government revenue and spending would also be important to understand how revenue and spending behave in the long run. To do this, vector error correction model was used. The variables considered were expenditure, total revenue, oil revenue, non-oil revenue and crude oil price. The result shows that there are three cointegrating relationship i.e. revenue on expenditure (at $1 \%$ critical value), oil revenue on expenditure (at $1 \%$ critical value) and non-oil revenue on expenditure (at $5 \%$ critical value). The cointegration and the vector error correction model is presented in Table 9.

Table 9. Vector Error Correction Result

\begin{tabular}{|c|c|c|c|c|c|}
\hline \multicolumn{6}{|c|}{$\begin{array}{l}\text { Sample(adjusted): } 19722011 \\
\text { Included observations: } 40 \text { after adjusting endpoints } \\
\text { Standard errors \& t-statistics in parentheses }\end{array}$} \\
\hline Cointegrating Eq: & CointEq1 & & & & \\
\hline EXPN(-1) & 1.000000 & & & & \\
\hline REV(-1) & $\begin{array}{r}-9.062512 \\
(3.11028) \\
(-2.91373) \\
\end{array}$ & & & & \\
\hline OREV(-1) & $\begin{array}{l}6.758237 \\
(2.45830) \\
(2.74915)\end{array}$ & & & & \\
\hline NOREV(-1) & $\begin{array}{l}1.410752 \\
(0.69008) \\
(2.04433) \\
\end{array}$ & & & & \\
\hline $\mathrm{COP}(-1)$ & $\begin{array}{l}0.228127 \\
(0.14407) \\
(1.58345)\end{array}$ & & & & \\
\hline $\mathrm{C}$ & 1.006701 & & & & \\
\hline Error Correction: & $\mathrm{D}(\mathrm{EXPN})$ & $\mathrm{D}(\mathrm{REV})$ & $\mathrm{D}(\mathrm{OREV})$ & D(NOREV) & $\mathrm{D}(\mathrm{COP})$ \\
\hline CointEq1 & $\begin{array}{r}-0.077362 \\
(0.08846) \\
(-0.87456) \\
\end{array}$ & $\begin{array}{r}-0.074529 \\
(0.11728) \\
(-0.63547) \\
\end{array}$ & $\begin{array}{r}-0.224102 \\
(0.14224) \\
(-1.57556) \\
\end{array}$ & $\begin{array}{l}0.145358 \\
(0.11697) \\
(1.24272) \\
\end{array}$ & $\begin{array}{r}-0.205569 \\
(0.10809) \\
(-1.90185) \\
\end{array}$ \\
\hline R-squared & 0.198735 & 0.096563 & 0.153563 & 0.220488 & 0.164115 \\
\hline Adj. R-squared & 0.053051 & -0.067698 & -0.000335 & 0.078759 & 0.012136 \\
\hline Sum sq. resids & 0.398739 & 0.700922 & 1.030967 & 0.697190 & 0.595361 \\
\hline
\end{tabular}

Source: Authors Estimation using Eviews 
The impulse response function was derived from the vector error correction model. Expenditure was shocked with one standard innovation around its standard error. The trend reveals that a positive shock in total revenue raises expenditure in the first two years and then stabilizes in the subsequent years. A negative shock in revenue however, pulls down expenditure in the immediate years and falls even faster in the subsequent years. When separated into oil and non-oil revenue, public expenditure however, happens to maintain a stable and rising trend despite the direction of the shock. This suggests that, designing policies to be used for stabilization of oil and non-oil revenue would be useful in stabilizing public expenditure in periods of domestic and external shock. Lastly, a shock in crude oil price however, was found to have a drastic effect on expenditure. A positive shock in crude oil price was found to increase expenditure slightly above the line of origin which in this case is synonymous to the balanced budget line, but quickly goes below the line of origin signaling a budget deficit regime. A negative shock in crude oil price however, drags expenditure down immediately and widens over time. This implies that the fluctuation of crude oil price is also a major factor that determines the size of public expenditure in Nigeria thus, a stable bench mark should be used in forecasting revenue from crude oil that takes into account possibility of a negative oil price shock. Further actions to improve revenue from non-oil sources would also be important to enhance sustainable growth and development in Nigeria. The impulse response trend is shown in Figure 1.

Response to One S.D. Innovations \pm 2 S.E.

Response of EXPN to REV

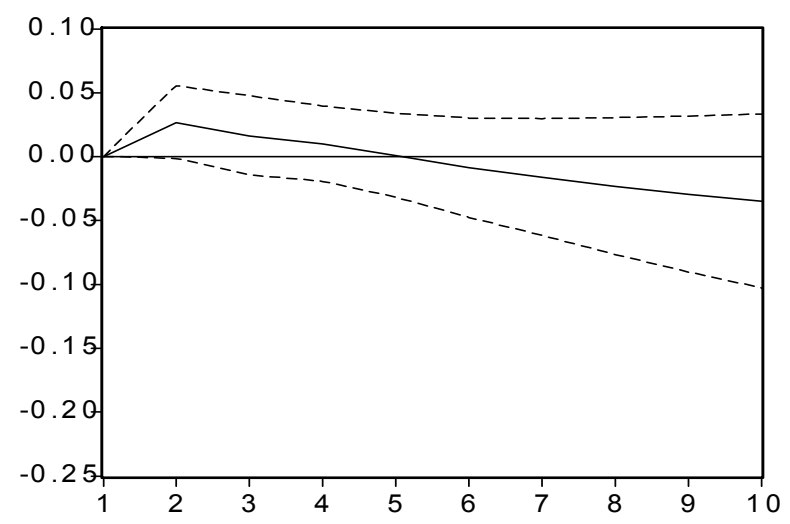

Response of EXPN to NOREV

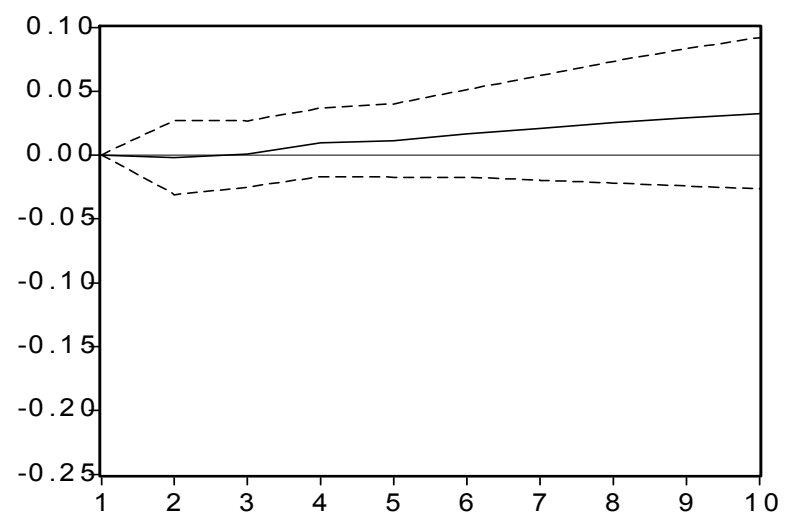

Response of EXPN to OREV

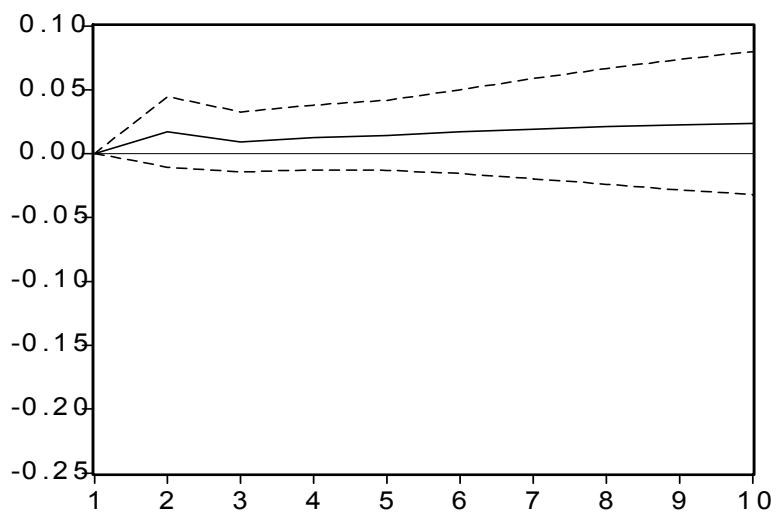

Response of EXPN to COP

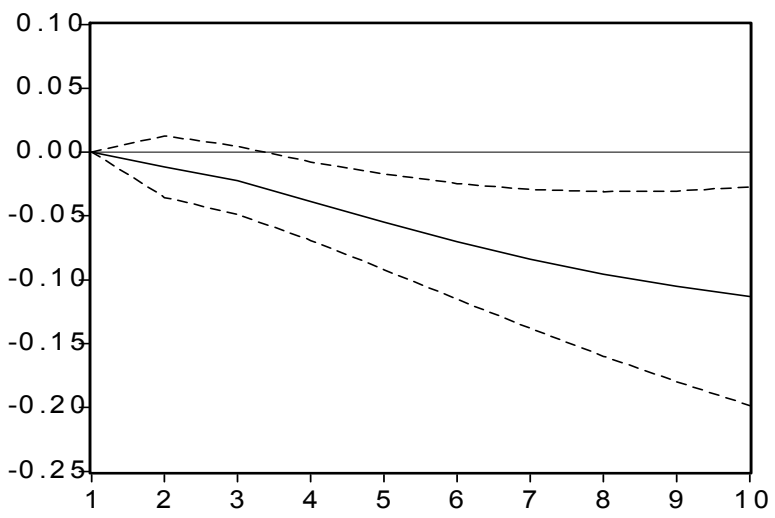

Figure 1. Nigeria: Impulse Response Function of Expenditure to Revenue

Source: Authors Presentation using Eviews 


\section{Discussions}

Several studies have examined the relationship between total government expenditure and revenue for various countries. The literature for Nigeria however still offers some methodological gaps and useful tips for policy on expenditure management. This paper tests the revenue-spend hypothesis for Nigeria. Total public expenditure was used as proxy for expenditure while revenue, oil revenue, non-oil revenue and crude oil prices were used to represent the revenue side. Correlation analysis was used to establish the degree of association among the variables while granger-causality test was used to test for the direction of influence between revenue and expenditure. The static direction of impact was then established using ordinary least square technique while the dynamic direction of impact was estimated using lagged regression model. The cointegration relationship was tested using vector error correction model and finally the response of expenditure to a shock in total revenue, oil revenue, non-oil revenue and crude oil price was tested using impulse response functions obtained from the vector error correction model. It was found that revenue and expenditure are highly correlated at about $90 \%$ and that the direction of causality between revenue and expenditure is positive and unidirectional running from revenue to expenditure. The vector error correction model found that there are three cointegrating relationship connecting expenditure to revenue, oil revenue and non-oil revenue implying that a shock in revenue has consequences for public spending. The impulse response function showed that a positive shock in revenue through crude oil price raises expenditure and narrows the deficit spending gap. A negative shock on the other hand, steepens public expenditure and widens the deficit spending gap. Though the shock from oil revenue and non-oil revenue on public expenditure seem to have the same spread effect, but negative shock from non-oil revenue drags expenditure down by a much lesser extent compared to a negative shock from oil revenue.

The policy implication is that while positive shocks from the international crude oil market could boost revenue in Nigeria hence translating into higher revenue, a negative shock would however, decrease oil-revenue and translate into widening spending deficit. The benchmark for crude oil price should therefore be kept at a level that recognizes possibility of international crude oil price decline. The need to move towards clean energy by de-emphasizing use of non-renewable energy in the face of climate change is another factor that could accelerate the rate of decline in the future. Furthermore; efforts should be made to boost non-oil revenue as a negative shock from this source of revenue was found to have a lesser impact on expenditure. One way to do this would be to commit part of the excess crude revenue account to boosting the performance of non-oil sector.

\section{Conclusion}

The paper examines the revenue-spending hypothesis for Nigeria using macro data from 1970 to 2011. Correlation analysis, granger causality test, regression analysis, lag regression model, vector error correction model and impulse response analysis were the techniques used for analysis. The paper found that revenue and expenditure are highly correlated and that causality runs from revenue to expenditure in Nigeria. The vector error correction model also confirms that there is a significant long run relationship between revenue and expenditure implying that disequilibrium in expenditure can be corrected in the long run through policies that adjust oil and non-oil sector revenues. The lagged regression model showed that the positive relationship between revenue and expenditure reverts to negative at lag five thereby justifying the need for the use of medium term expenditure framework to monitor expenditure patterns in the short to medium term. The paper concludes that short term shocks from crude oil price passes through oil revenue to affect expenditure. This has led to swings in public expenditure pattern with sustained increase of recurrent expenditure over capital that has consequences for economic growth. However, there are some areas for further studies. There would be need to test for structural breaks over the period studied to support the conclusions obtained from the impulse response shocks. There would also be need to carry out a cross country study for the correlation between government expenditures and revenues for oil-exporting countries in other to provide cross country evidence on the relationship between public expenditure and revenue.

\section{References}

Aregbeyen, O., \& T. M. Ibrahim. (2012). Testing the Revenue and Expenditure Nexus in Nigeria: An Application of the Bound Test Approach. European Journal of Social Sciences, 27(3), 374-380.

Mehmood, R., \& S. Sadiq. (2010). The Relationship between Government Expenditure and Poverty: A Cointegration Analysis. Romanian Journal of Fiscal Policy, 1(1), 29-37.

Mehrara, M, M. Pahlavani, \& Y. Elyasi. (2011). Government Revenue and Government Expenditure Nexus in Asian Countries: Panel Cointegration and Causality. International Journal of Business and Social Science, 2(7), 199-207. http://dx.doi.org/10.2139/ssrn.1977987 
NCEMA. (2004). Structural Adjustment Programme in Nigeria: Causes, Processes, and Outcomes. National Centre for Economic Management \& Administration. A publication of National Centre for Economic Management \& Administration (NCEMA), for Global Development Network. Accessed online on the $23^{\text {rd }}$ July 2012 from http://depot.gdnet.org/cms/grp/general/Nigeria_proposal.pdf

Obioma, E. C., \& U. M. Ozughalu. (2010). An Examination of the Relationship between Government Revenue and Government Expenditure in Nigeria: Cointegration and Causality Approach. Central Bank of Nigeria Economic and Financial Review, 48(2), 35-57.

Stoian, A. (2008). Analyzing Causality between Romania's Public Budget Expenditures and Revenues. Theoretical and Applied Economics, 11(11), 60-64. 